
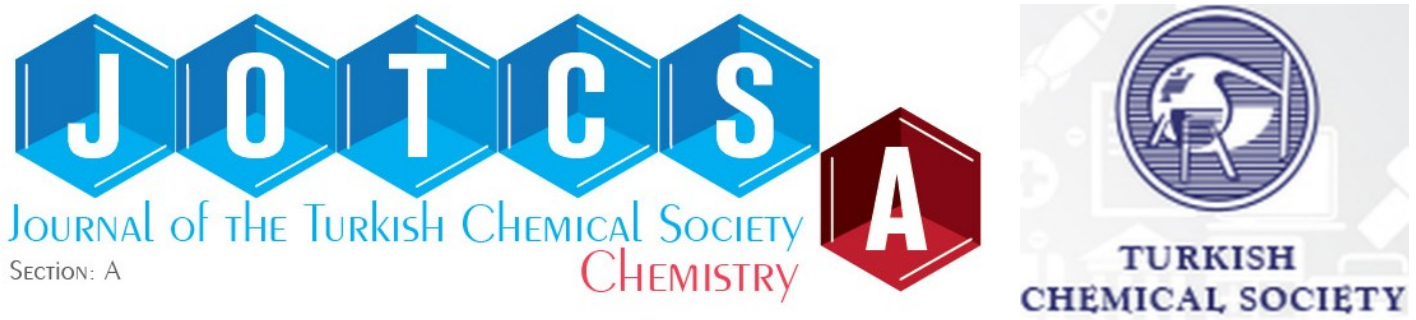

\title{
Vermicompost as a Potential Adsorbent for the Adsorption of Methylene Blue Dye from Aqueous Solutions
}

\author{
Zeynep CİĞEROĞLU ${ }^{1}$ Q and Eyup YILDIRIR ${ }^{1}$ (D)
}

Uşak University, Department of Chemical Engineering, 64400 Uşak/Turkey

\begin{abstract}
Vermicompost (VC) as a low cost and waste-derived material was used as an adsorbent to remove textile dye effluents from the wastewater. Methylene blue (MB) was selected as a representative of dye effluents and its adsorption to VC was investigated. The effect of parameters such as $\mathrm{pH}$, adsorption time, and the initial concentration of MB were determined via lab-scale batch experiments. The highest adsorption capacity of VC was reached when the $\mathrm{pH}$ of the solution was 4 . The equilibrium was maintained after 90 minutes of operation since the removal percentage of MB was stabilized at $99 \%$. The pseudo-second-order kinetic model described the most appropriate adsorption kinetic behavior. Both Langmuir $\left(R^{2}=0.9891\right)$ and Freundlich isotherms $\left(R^{2}=0.9895\right)$ fitted very well to the experimental data. Based on these results, vermicompost can be evaluated as an alternative adsorbent for the removal of dye effluents.
\end{abstract}

Keywords: Adsorption, Isotherms, Kinetics, Methylene Blue, Vermicompost.

Submitted: August 23, 2020. Accepted: October 20, 2020.

Cite this: Ciğeroğlu Z, Yildirir E. Vermicompost as a Potential Adsorbent for the Adsorption of Methylene Blue Dye from Aqueous Solutions. JOTCSA. 2020; 7(3): 893-902.

DOI: https://doi.org/10.18596/jotcsa.784357

*Corresponding author. E-mail:zeynep.ilbay@usak.edu.tr, zilbay@gmail.com.

Tel: +90276221 2121/2774.

\section{INTRODUCTION}

Composting and vermicomposting are two biological processes to convert organic wastes such as sewage sludge, municipal solid waste, etc. into soil amendments (1). Composting is homogenization of mixed organic wastes by means of thermophilic process at a temperature range of 45 to $65^{\circ} \mathrm{C}$, while vermicomposting is the stabilizing the organic wastes or compost by the digestion of earthworms and micro-organisms at $35{ }^{\circ} \mathrm{C}(1,2)$. The final products after two processes have nutrients for the soil, humic acid, and metals together with high moisture contents; compost with 40 to $60 \mathrm{wt} \%$ and vermicompost with 70 to 90 wt.\% respectively (3).

Converting organic wastes into vermicompost is perceived as environmentally and economically sustainable since the product could be used as a promoter for plant growth and soil amendment.
However, there are reports in the literature criticizing the usage of compost and vermicompost as soil amendments since they may have pathogens and heavy metals which are hazardous for the human. Although vermicomposting reduce somewhat human pathogens, regulations by the governments limit the usage of compost and vermicompost due to their hazardous nature to human health (4). This situation influenced the researchers to investigate alternative usage areas for compost and vermicompost different from agricultural purposes. Vermicompost has gained attention to be used as an adsorbent to remove organic and inorganic contaminants in the wastewater and studies showed that due to its high surface area and functional groups existing naturally, making vermicompost an effective adsorbent (5). Especially the humic substances in the organic fraction of vermicompost provide the high surface area with high porosity, high density of 
negative charges, and noticeable cationic exchange capacity.

Adsorption is a widely known technique applied to wastewater to remove organic and inorganic contaminants. Activated carbon is one of the most promising adsorbents according to the studies in the literature (6). However, its high cost limits its applicability therefore investigation of alternative adsorbents with low cost and appropriate characteristics is crucial. In this regard, compost, clays, chitosan, peats, biochar, etc. were utilized and a variety of contaminants tested in order to extract their potential as an effective adsorbent (7). Vermicompost, on the other hand, has proper physical and chemical properties to be evaluated as an absorbent, and its low cost attracts researchers to investigate its adsorption capability. Currently, vermicompost's price is around $20 \mathrm{TRY} / \mathrm{kg}$ and according to a recent report, its annual production rate was about 20,000 tonnes in 2017, in Turkey (8).

Early studies focused on the metal removal from the wastewater and the results were promising. Vermicompost produced from cattle manure was utilized in a glass column to determine its adsorption capability on $\mathrm{Cu}, \mathrm{Ni}$ and $\mathrm{Zn}$, and it was proven that higher adsorption rates were achieved compared to various adsorbents such as sewage sludge, apple residues, peat moss etc. (5). Zhu et al. reported that high removal efficiencies of $\mathrm{Pb}$ and $\mathrm{Cd}$ from wastewater stream were possible when cow manure and its vermicompost were used as adsorbent. They also determined that the performance of vermicompost was better and mainly the functional groups such as aliphatic alcohols, aromatic acids, carbonates, and phosphates contributed to the efficient removal of the metals (9). Pesticide methylparathion removal from water stream via adsorption onto vermicompost was studied as well and the results suggested that experimental data fitted to the Langmuir linear model yielding $0.17 \mathrm{mg} / \mathrm{g}$ of maximum adsorption capacity (10).

Apart from the metals and pesticide, dye effluents such as congo red, crystal violet, etc. were also adsorbed onto vermicompost and results looked promising $(11,12)$. However, there is still more work to be carried out to figure out the optimum conditions for the process. Especially for Turkey, producing a versatile, low cost, and highly efficient adsorbent is important, as textile and leather industrial wastewater contains great amounts of dye effluents. In addition, only around $0.38 \%$ of 34.500 tonnes of MSW produced in Turkey is composted annually, according to TUIK (13). Since compost can be used for vermicompost production, Turkey has a great potential to reach vast production figures if alternative routes for vermicompost utilization could be established. In this study, vermicompost was evaluated as a potential adsorbent for methylene blue adsorption as a model dye effluent. As a cationic dye, methylene blue could be contained in the textile and leather industrial wastewater since it is used in silk and wool dyeing processes. The high concentration of methylene blue is regarded as hazardous, and avoiding its leakage to soil and rivers is crucial (14).

The primary aim of this study was to examine the influences of the adsorption conditions such as the initial concentration of $\mathrm{MB}, \mathrm{pH}$ of media on the adsorption capacity of MB onto VC. In addition, kinetic models (the first and second-pseudo-order, Intraparticular and Elovich models) and four isotherm models (Langmuir, Freundlich, Temkin and Dubinin-Radushkevich) were utilized to determine their compatibility with the experimental data.

\section{MATERIALS AND METHODS}

\section{Materials}

Sodium chloride, hydrochloric acid, sodium hydroxide, and methylene blue were purchased from Sigma Aldrich. Bidistilled water was used in the whole experimental process. Vermicompost (VC) was purchased from a local producer from İzmir, and it was produced from sewage sludge compost and sawdust. Initially, vermicompost was dried and sieved to yield a particle size of $0.125<D p<0.600$ [mm] for homogenization of the sample. Vermicompost sample was oxidized in a furnace at $500{ }^{\circ} \mathrm{C}$ for 6 hours and its ash content was determined as 31.05 wt. \%.

\section{Sorption Experiments}

Methylene Blue (MB) solutions at various $\mathrm{pH}$ values were prepared and $10 \mathrm{~mL}$ of specified concentration of MB solutions were poured into an erlenmeyer flask along with $0.1 \mathrm{~g}$ of VC sample. The sorption experiments were carried out in an incubator shaker operating at $100 \mathrm{rpm}$ and $25^{\circ} \mathrm{C}$ temperature. After the sorption experiments were completed, the solutions in the Erlenmeyer flasks were pulled out and centrifuged at $400 \mathrm{rpm}$ for 1 minute. The initial and the supernatant concentrations were read with the help of UV-Vis spectrophotometer (Perkin Elmer, Lambda 365) at $\lambda$ max: $664 \mathrm{~nm}$. Adsorption capacity (AC) and removal yield (R\%) were determined according to equations 1 and 2 , respectively.

$$
\begin{aligned}
& A C=\frac{\left(C_{i}-C_{e}\right) * V}{m} \\
& R \%=\frac{\left(C_{i}-C_{e}\right) * 100}{C_{i}}
\end{aligned}
$$

$\mathrm{C}_{\mathrm{i}}$ and $\mathrm{C}_{\mathrm{e}}$ represent the initial and equilibrium concentration of the solution $\left(\mathrm{mgL}^{-1}\right)$, respectively. $\mathrm{m}$ denotes the mass of VC $(\mathrm{g})$.

\section{Determination of pHpzc}


Slightly modified potentiometric titration method of Mohan et al. 2014 (15) was utilized to determine the point of zero charge. Briefly, $0.1 \mathrm{~g}$ of VC was added to $10 \mathrm{~mL}$ of $0,1 \mathrm{M} \mathrm{NaCl}$ solutions having $\mathrm{pH}$ values in the range of 2 to 12 . The solutions were placed into the shaking water bath for 24 hours. After that, supernatant $\mathrm{pH}$ values were measured and a plot consisting of $\mathrm{pH}$ of initial solutions versus $\mathrm{pH}$ of final solutions was obtained.

\section{Adsorption Kinetics}

Batch kinetics were assessed with the help of appropriate kinetic models so that the adsorption rates and mechanism could be defined. In this research, the pseudo-first order (Eq. 3) (16), the pseudo-second-order (Eq. 4) (17), Intraparticular (Eq. 5) (18) and Elovich kinetic models (Eq. 6) (19) were applied to experimental data. The coefficient of determination $\left(R^{2}\right)$ was calculated for each kinetic model to determine the best fit model. $\log \left(q_{e}-q_{t}\right)=\log q_{e}-\frac{k_{p}}{2.303} t$

$\frac{t}{q_{t}}=\frac{1}{k_{2} q_{e}^{2}}+\frac{t}{q_{e}}$

$q_{t}=k_{p} t^{0.5}+c$

$q_{t}=\frac{1}{\beta} \ln (\alpha \beta)+\frac{1}{\beta} \ln t$

Where $\mathrm{q}_{\mathrm{e}}$ is the equilibrium adsorption capacity $(\mathrm{mg} / \mathrm{g}), \mathrm{k}_{1}$ is pseudo-first-order constant $\left(\mathrm{min}^{-1}\right), \mathrm{k}_{2}$ is the pseudo-second-order constant $(\mathrm{g} / \mathrm{mg} \cdot \mathrm{min}), \beta$ is the Elovich equation exponent $(\mathrm{g} / \mathrm{mg}), k_{p}$ is diffusion constant.

\section{Isotherm Models}

In order to appraise the adsorption behavior, four isotherm kinetic models were utilized. Table 1 represents the Langmuir (20), Freundlich (21), Temkin (22), and Dubinin-Radushkevich (D-R)(23) isotherm models.

Table 1. Applied Isotherm Models with their equations and units.

\begin{tabular}{|c|c|c|}
\hline Models & Equations & Units \\
\hline Langmuir & $\frac{C_{e}}{q_{e}}=\frac{1}{q_{\max } K_{L}}+\frac{C_{e}}{q_{\max }}$ & 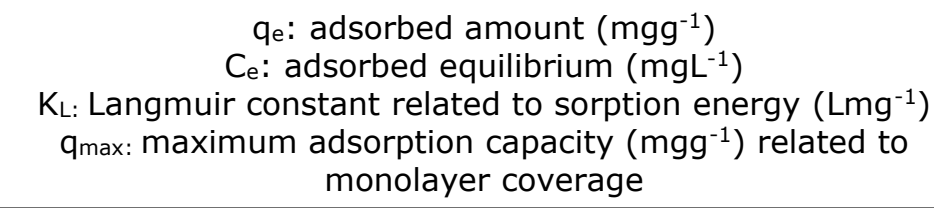 \\
\hline Freundlich & $\ln q_{e}=\ln \left(K_{F}\right)+\frac{1}{n} \ln C_{e}$ & $\begin{array}{c}\mathrm{C}_{\mathrm{e}}: \text { adsorbed equilibrium }\left(\mathrm{mgL}^{-1}\right) \\
\mathrm{K}_{\mathrm{F}}: \text { Freundlich constant } \\
\quad\left(\mathrm{mgg}^{-1}\right)\left(\mathrm{Lmg}^{-1}\right)^{\mathrm{n}} \\
1 / \mathrm{n}: \text { intensity of adsorption }\end{array}$ \\
\hline Temkin & $\begin{array}{c}q_{e}=B \ln a_{T}+B \ln C_{e} \\
B=\frac{R T}{b_{T}}\end{array}$ & $\begin{array}{c}\text { Ce: adsorbed equilibrium }\left(\mathrm{mgL}^{-1}\right) \\
\text { at: equilibrium bond constant } \\
\text { B, } \mathrm{b}_{\mathrm{T}} \text { : Temkin constants }\end{array}$ \\
\hline $\begin{array}{l}\text { Dubinin- } \\
\text { Radushkevich }\end{array}$ & $\begin{array}{l}\ln q e=\ln q_{m}-\beta \varepsilon^{2} \\
\varepsilon=R T \ln \left(1+\frac{1}{C_{e}}\right) \\
E=\frac{1}{\sqrt{ } 2 \beta}\end{array}$ & $\begin{array}{c}\text { Ce: adsorbed equilibrium }\left(\mathrm{mgL}^{-1}\right) \\
\mathrm{q}_{\mathrm{m}} \text { : maximum adsorption capacity }\left(\mathrm{mgL}^{-1}\right) \\
\varepsilon: \text { Polanyi potential } \\
\beta: \text { activity coefficient } \\
\left(\mathrm{mol}^{2} \mathrm{~J}^{-2}\right) \\
\mathrm{R}: \text { gas constant }\left(8.314 \mathrm{kJmol}^{-1} \mathrm{~K}^{-1}\right) \\
\text { E: mean adsorption Energy }\left(\mathrm{kJmol}^{-1}\right)\end{array}$ \\
\hline
\end{tabular}

\section{RESULTS AND DISCUSSION}

\section{Effect of pH on methylene blue removal mechanisms}

The impact of $\mathrm{pH}$ on the $\mathrm{MB}$ sorption was investigated with batch experiments performed in a
$\mathrm{pH}$ range of 2-10 and the outcomes were shown in the Figure 1 . The maximum MB removal was achieved when $\mathrm{pH}$ of the solution was 4 . Therefore, all adsorption experiments were executed at $\mathrm{pH} 4$. 


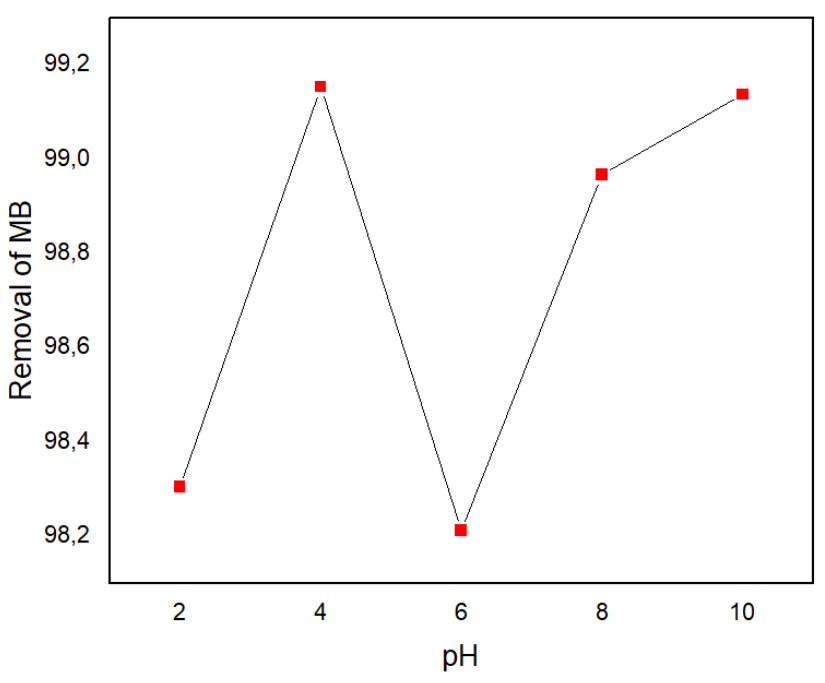

Figure 1. $\mathrm{pH}$ effect on the removal of MB.

Moreover, the point of zero charge (pHpzc) was measured as 8.51 as shown in Figure 2. At this $\mathrm{pH}$, the surface charge of $\mathrm{VC}$ is zero. When $\mathrm{pH}<\mathrm{pHpzc}$, the surface of vermicompost has positive charge. In the opposite cases, the functional groups of vermicompost are negatively charged. $\mathrm{MB}$ is a cationic dye as it is known. Furthermore, the pKa of MB is 3.8; the cationic species of MB are dominant in the solutions above the value of pKa (24). The electrostatic adherence has occurred between the adsorbent and adsorbate at $\mathrm{pH} 4$.

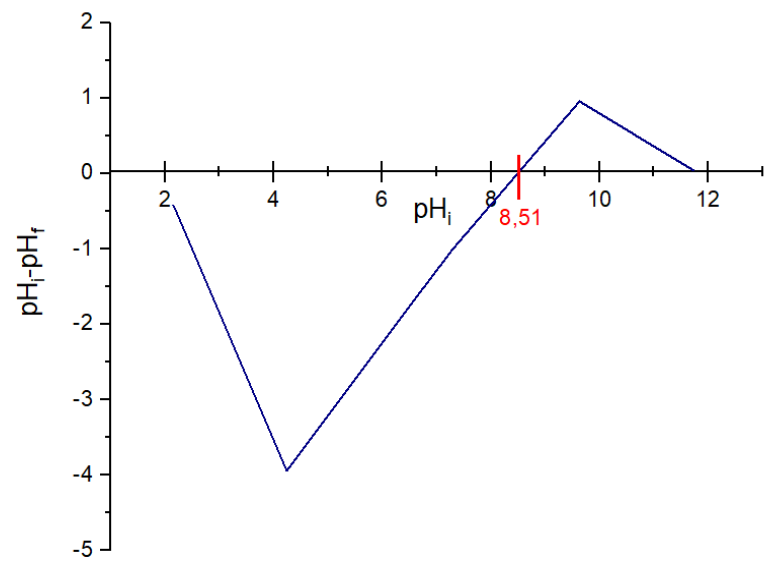

Figure 2. The point of zero charge of VC.

Effect of time and initial concentration of MB The impact of time on MB adsorption onto $\mathrm{VC}$ was shown in Figure 3. Methylene blue adsorption onto VC was so rapid that adsorption equilibrium could be achieved within 60 minutes. As the vacant sites on the surface of VC were occupied with methylene blue, adsorption process happened very slowly by virtue of the small number of vacant sites and $99 \%$ removal of MB was achieved at 90 min. Besides, adsorption capacity enhanced with the higher initial concentration of $\mathrm{MB}$, this phenomenon indicated in Figure 4. Initial concentration raises mass transfer between the adsorbate and the adsorbent owing to the driving force. 


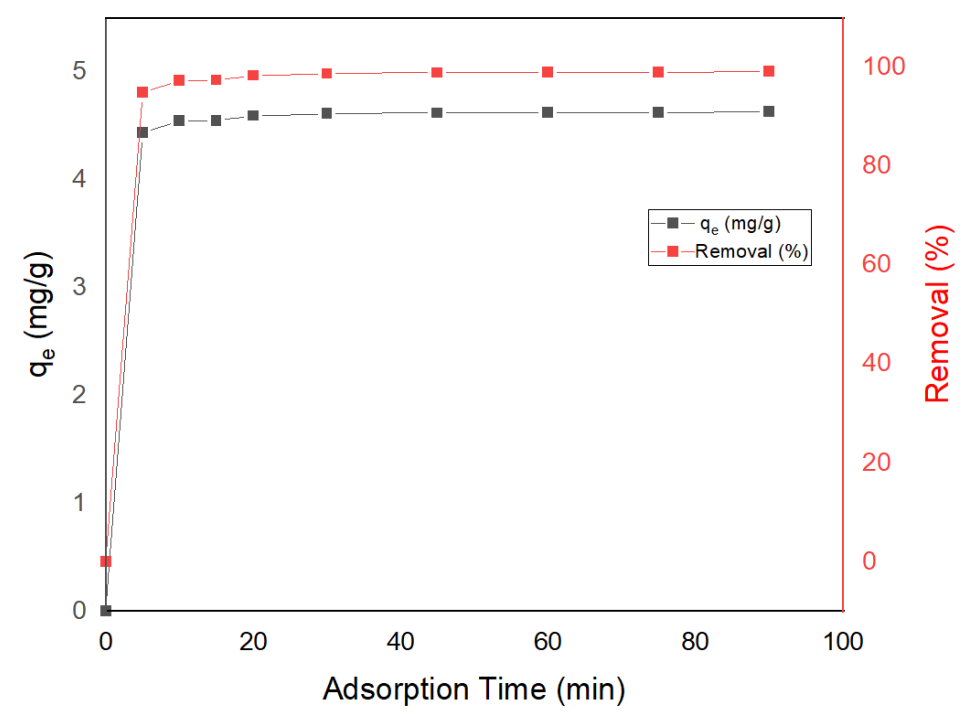

Figure 3. The effect of time on MB adsorption onto VC.

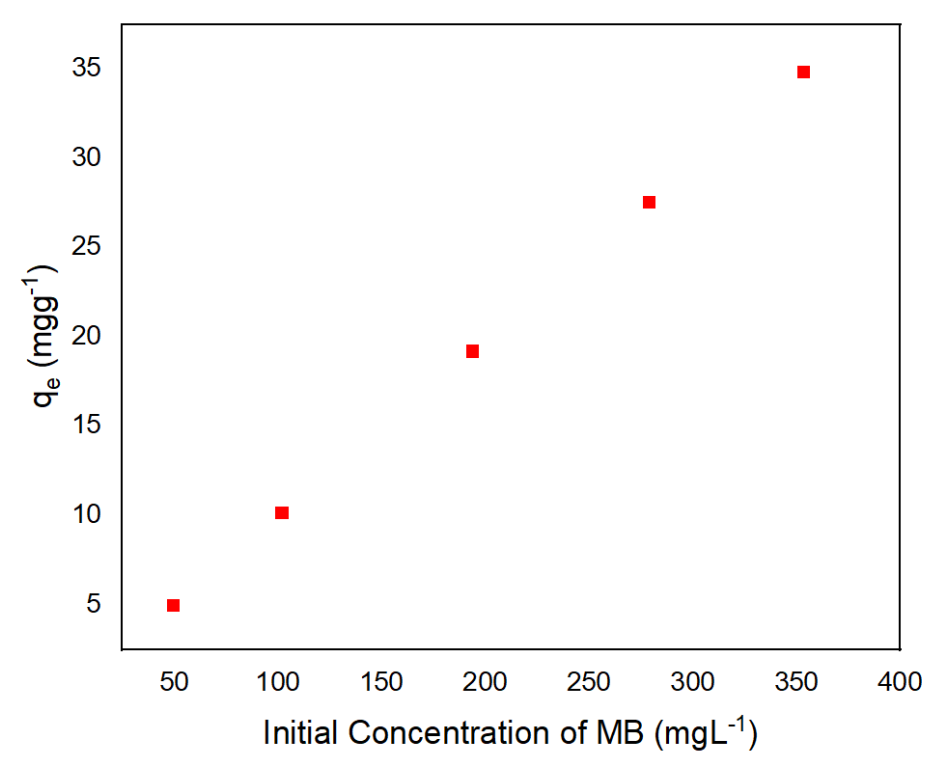

Figure 4. The effect of initial concentration on the adsorption capacity of MB onto VC.

\section{Kinetic isotherm models}

It can be deduced from Table 2 that chemisorption occurred according to the pseudo-second-order model. The first step of sorption was so fast owing to the large number of active sites of VC. With the increasing adsorption time, vacant sites of the surface were gradually decreased. As a result, all active surface was totally filled the adsorbate and adsorption process reached the equilibrium (25). The coefficients of determination of the kinetic models applied as shown in Figure 5 indicating that the pseudo-second-order model had the finest linear fit to the experimental data. Also, adsorption onto the VC comprised of two stages represented a multilinearity. Within the $5 \mathrm{~min}$, the rapid MB adsorption took place. Then, the adsorption process has slightly risen. The boundary layer diffusion constitutes the first step, and the second stage was ascribed to the intraparticle diffusion (26). 
Table 2. Kinetic parameters of applied kinetic models for MB adsorption onto VC at $298 \mathrm{~K}$.

\begin{tabular}{ccc}
\hline Models & $\begin{array}{c}\text { Model } \\
\text { parameter }\end{array}$ & VC \\
\hline Pseudo-first- & $\mathrm{qe}$ & 0.6760 \\
order kinetics & $\mathrm{k}_{1}$ & 0.0914 \\
& $\mathrm{R}^{2}$ & 0.7571 \\
\hline Pseudo- & $\mathrm{qe}$ & 4.63 \\
second-order & $\mathrm{k}_{2}$ & 1.58 \\
kinetics & $\mathrm{R}^{2}$ & 1.0 \\
\hline \multirow{3}{*}{ Intraparticular } & $\mathrm{K}_{\mathrm{p}}$ & 0.3846 \\
& $\mathrm{C}_{1}$ & 1.9457 \\
& $\mathrm{R}^{2}$ & 0.5208 \\
\cline { 2 - 3 } Elovich & $\mathrm{a}$ & 1.104 \\
& $\beta$ & 3.758 \\
& $\mathrm{R}^{2}$ & 0.6887 \\
\hline
\end{tabular}
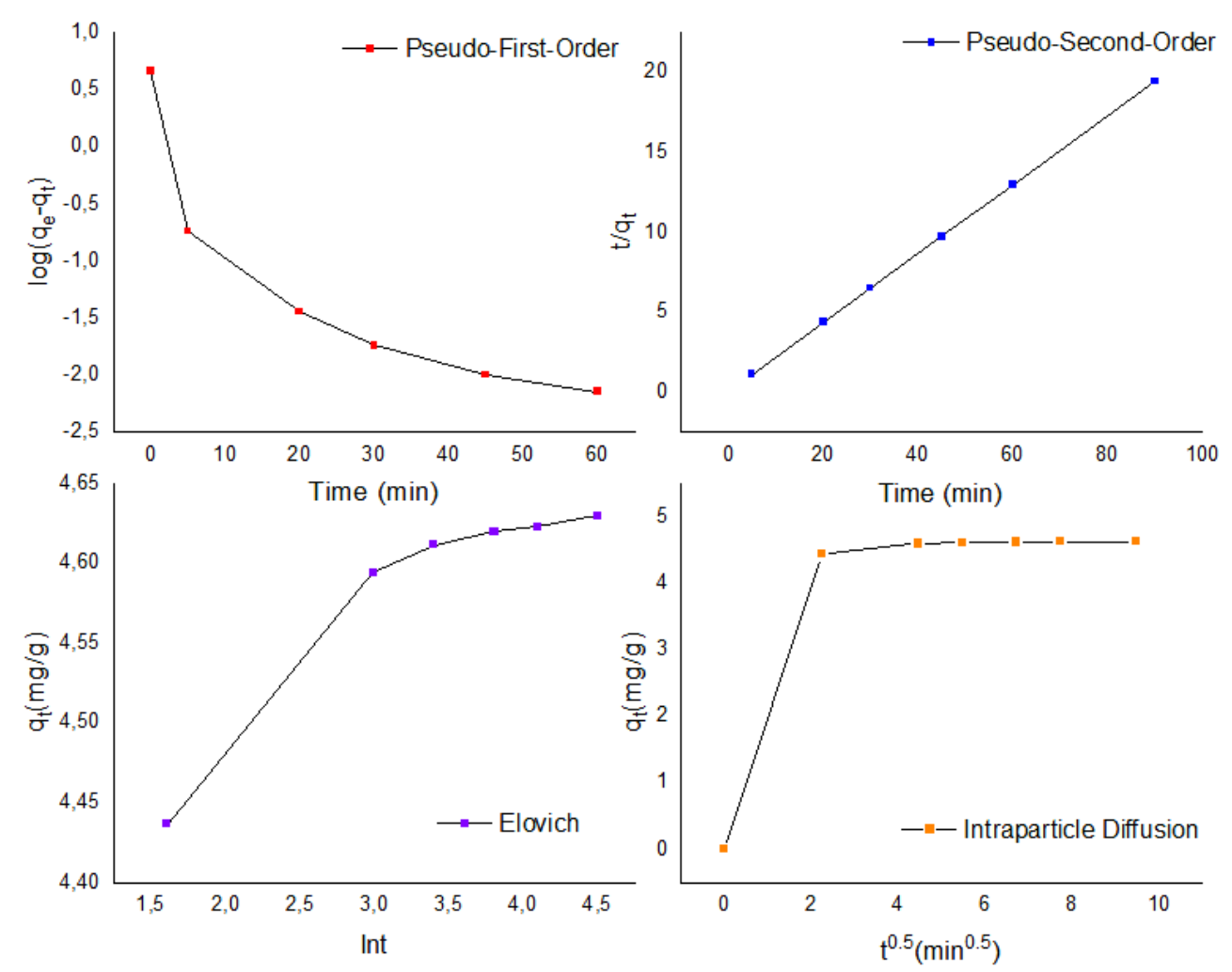

Figure 5. Applied kinetic models on the MB's adsorption onto the VC a) pseudo-first-order b) pseudosecond-order c) Elovich d) Intraparticle diffusion.

\section{Adsorption isotherm models results}

The calculated parameters for isotherm models applied in this research are summarized in Table 3. Furthermore, a plot was drawn by using nonlinear regression analysis showing the conformity of the isotherm models to experimental data in Figure 6. It can be said that both Langmuir and Freundlich isotherm models were excellent-fitted to empirical data. In fact, the coefficients of determination were so close to each other in all models. The Freundlich isotherm gave an idea that adsorption happened on the heterogeneous surface. Besides, there were no equal binding sites (27). 
Table 3. The parameters of applied isotherm models for MB adsorption onto VC at $298 \mathrm{~K}$.

\begin{tabular}{ccc}
\hline Models & $\begin{array}{c}\text { Model } \\
\text { parameter }\end{array}$ & VC \\
\hline & qe(calculated) & 34.7900 \\
Langmuir & qmax & 58.4795 \\
& $\mathrm{KL}_{\mathrm{L}}$ & 0.2070 \\
& $\mathrm{R}^{2}$ & 0.9891 \\
\hline \multirow{3}{*}{ Freundlich } & $\mathrm{n}$ & 1.3077 \\
& $\mathrm{~K}_{\mathrm{F}}$ & 9.5410 \\
& $\mathrm{R}^{2}$ & 0.9895 \\
\hline \multirow{4}{*}{ Temkin } & $\mathrm{B}$ & 10.0620 \\
& $\mathrm{a}_{\mathrm{T}}$ & 3.1760 \\
& $\mathrm{~b}_{\mathrm{T}}$ & 246.3545 \\
& $\mathrm{R}^{2}$ & 0.9832 \\
\hline \multirow{3}{*}{ Dubinin- } & $\mathrm{Qm}^{2}$ & 23.8456 \\
Radushkevich & $\beta \times 10^{7}$ & 2.0000 \\
& $\mathrm{E}$ & 1581.1390 \\
\hline
\end{tabular}

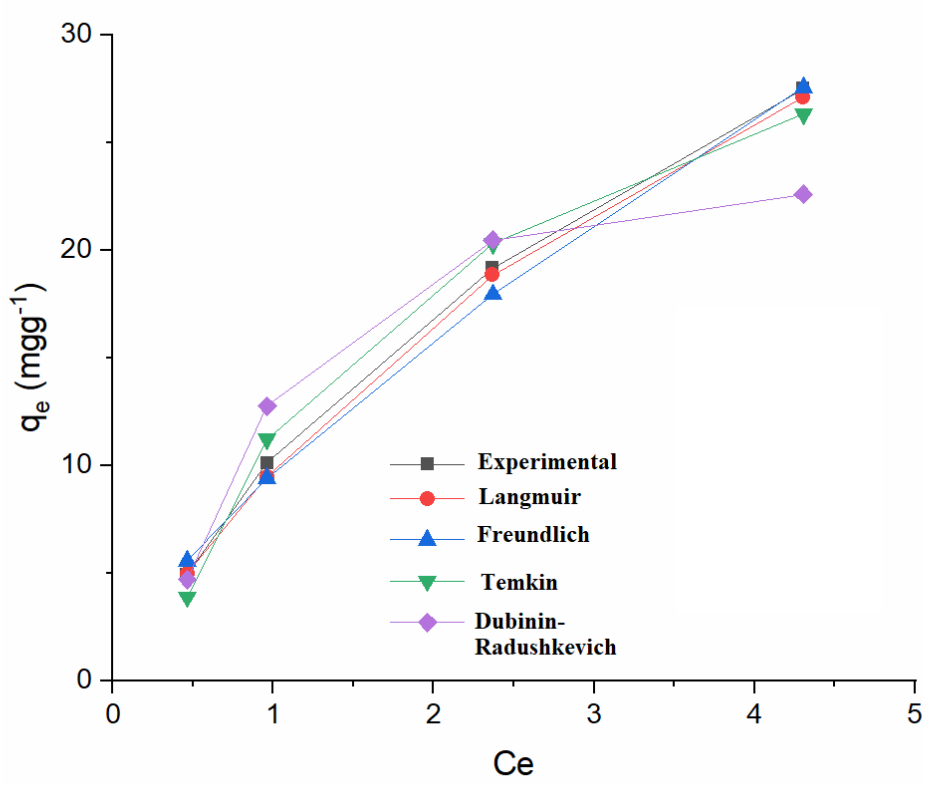

Figure 6. Adsorption isotherms of MB onto VC.

\section{FTIR Analyses of the Adsorbent}

FTIR analyses of raw vermicompost and vermicompost after MB adsorption were carried out and resulting spectra are shown in Figure 7. Raw vermicompost's broad peak seen at $3368 \mathrm{~cm}^{-1}$ is corresponding to the - $\mathrm{OH}$ band of hydroxyl groups which could belong to phenolic compounds. Furthermore, it can be inferred from the literature survey of vermicompost, $\mathrm{N}-\mathrm{H}$ stretching band from amides and amines are observed in the range of $3300-3500 \mathrm{~cm}^{-1}(28)$. The sharp peak at $1634 \mathrm{~cm}^{-1}$ is attributed to $-\mathrm{OH}$ band. The intense peak at 1031 $\mathrm{cm}^{-1}$ may be assigned to stretching $\mathrm{C}-\mathrm{O}$ group of polysaccharides. When the FTIR spectrum of vermicompost after MB adsorption was examined, the specific peak was detected at $1593 \mathrm{~cm}^{-1}$ corresponds to the $\mathrm{C}=\mathrm{C}$ due to the aromatic rings. The two lower signal peaks were observed at 1323 $\mathrm{cm}^{-1}$ and $1384 \mathrm{~cm}^{-1}$ owing to the $\mathrm{C}-\mathrm{N}$ stretching vibrations and $-\mathrm{OH}$ functional groups, respectively (29). Also, the symmetrical stretching $\mathrm{C}-\mathrm{H}$ of $\mathrm{CH}_{2}$ band appeared at $2928 \mathrm{~cm}^{-1}$ (28). The dramatic decrease on the magnitude of $-\mathrm{OH}$ peaks after the adsorption of MB onto VC could be evaluated to the chemisorption since the hydroxyl groups were neutralized. 


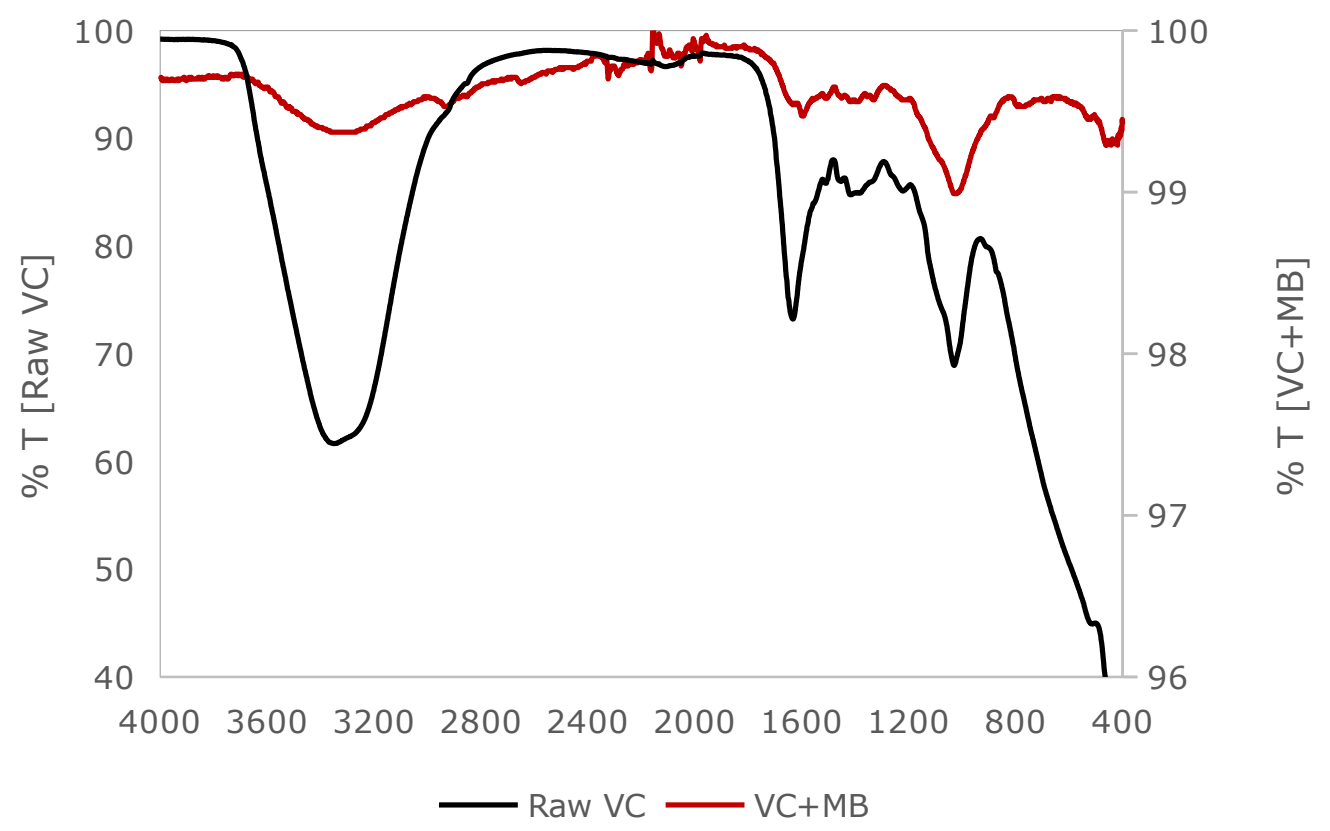

Figure 7. FTIR spectrum of Raw VC and MB adsorbed VC.

\section{CONCLUSION}

Vermicompost was evaluated as a cost-effective adsorbent in order to MB sorption from aqueous solution. The various kinetic models were applied to identify the reaction mechanism and the pseudosecond order kinetic model was matched with the experimental data, yielding the highest coefficient of determination $\left(R^{2}=1.0\right)$. The nonlinear regression results of the isotherms pointed out that Langmuir model fitted the empirical results better than the other isotherm models. The maximum adsorption capacity value was calculated as $58.48 \mathrm{mgg}^{-1}$ via the Langmuir isotherm. Furthermore, before and after the adsorption process, VC's functional groups were observed by FTIR. These results indicated the mechanism of the adsorption process between the VC and MB. Last but not the least, VC is a good candidate for the removal of MB.

\section{REFERENCES}

1. Domínguez J, Edwards CA, Subler S. A comparison of vermicomposting and composting methods to process animal wastes. Biocycle. 1997;April(April):57-9.

2. Zuccconi F, Bertoldi M. Compost pecification for the production and characterization of compost from municipal solid waste. Compost Prod Qual Use. 1987;

3. Tognetti $C$, Laos $F$, Mazzarino MJ, Hernández MT. Composting vs. Vermicomposting: A

Comparison of End Product Quality. Compost Sci Util [Internet]. 2005 Jan [cited 2020 Feb 20];13(1):613. Available from:

http://www.tandfonline.com/doi/abs/10.1080/1065
$657 X .2005 .10702212$

4. Eastman BR, Kane PN, Edwards CA, Trytek L, Gunadi B, Stermer AL, et al. The Effectiveness of Vermiculture in Human Pathogen Reduction for USEPA Biosolids Stabilization. Compost Sci Util [Internet]. 2001 Jan [cited 2020 Feb 21];9(1):3849. Available from:

https://www.tandfonline.com/action/journalInforma tion?journalCode $=$ ucsu 20

5. Matos GD, Arruda MAZ. Vermicompost as natural adsorbent for removing metal ions from laboratory effluents. Process Biochem. 2003 Sep $30 ; 39(1): 81-8$.

6. Paradelo $R$, Vecino $X$, Moldes AB, Barral MT. Potential use of composts and vermicomposts as low-cost adsorbents for dye removal: an overlooked application. Vol. 26, Environmental Science and Pollution Research. Springer Verlag; 2019. p. 21085-97.

7. Crini G. Non-conventional low-cost adsorbents for dye removal: A review. Vol. 97, Bioresource Technology. Elsevier; 2006. p. 106185.

8. Bellitürk K. Vermicomposting in Turkey: Challenges and opportunities in future. Eurasian J For Sci [Internet]. 2018 [cited 2020 Jul 7];6(4):3241. Available from: http://dergipark.gov.tr/ejejfs

9. Zhu W, Du W, Shen $X$, Zhang $H$, Ding $Y$. Comparative adsorption of $\mathrm{Pb} 2+$ and $\mathrm{Cd} 2+$ by cow manure and its vermicompost. Environ Pollut. 2017 Aug 1;227:89-97. 
10. Mendes CB, Lima GDF, Alves VN, Coelho NMM, Dragunski DC, Tarley CRT. Evaluation of vermicompost as a raw natural adsorbent for adsorption of pesticide methylparathion. Environ Technol [Internet]. 2012 Jan [cited 2020 Feb 28];33(2):167-72. Available from: https://www.tandfonline.com/action/journalInforma tion?journalCode $=$ tent 20

11. De Godoi Pereira M, Korn M, Santos BB, Ramos MG. Vermicompost for tinted organic cationic dyes retention. Water Air Soil Pollut. 2009 Jun $20 ; 200(1-4): 227-35$.

12. Yang G, Wu L, Xian Q, Shen F, Wu J, Zhang $Y$. Removal of Congo Red and Methylene Blue from Aqueous Solutions by Vermicompost-Derived Biochars. Singer AC, editor. PLoS One [Internet]. 2016 May 4 [cited 2019 Nov 17];11(5):e0154562. Available from:

https://dx.plos.org/10.1371/journal.pone.0154562

13. TÜİK. Türkiye İstatistik Kurumu [Internet]. Tarımsal Gübre İstatistikleri. 2019 [cited 2020 May 27]. Available from:

http://www.tuik.gov.tr/PreTablo.do?alt_id=1001

14. Ciğeroğlu Z, Haşimoğlu A, Özdemir OK. Synthesis, characterization and an application of graphene oxide nanopowder: methylene blue adsorption and comparison between experimental data and literature data. J Dispers Sci Technol [Internet]. 2020 [cited 2020 Jul 20]; Available from:

https://www.tandfonline.com/doi/abs/10.1080/0193 2691.2019.1710526

15. Mohan D, Kumar H, Sarswat A, AlexandreFranco M, Pittman CU. Cadmium and lead remediation using magnetic oak wood and oak bark fast pyrolysis bio-chars. Chem Eng J [Internet]. 2014 [cited $2020 \mathrm{Jul} 20$ ];236:513-28. Available from:

https://www.sciencedirect.com/science/article/pii/S 1385894713012503

16. Lagergren S. Zur Theorie der sogenannten Adsorption gelöster Stoffe. Zeitschrift für Chemie und Ind der Kolloide [Internet]. 1907 Jul [cited $2020 \mathrm{Jul} 22] ; 2(1): 15-15$. Available from: https://www.sid.ir/en/journal/ViewPaper.aspx? ID $=263167$

17. Ho YS, McKay G. Sorption of dye from aqueous solution by peat. Chem Eng J [Internet]. 1998 Jun [cited 2020 Jul 22];70(2):115-24. Available from:

https://linkinghub.elsevier.com/retrieve/pii/S09230 46798000761

18. Weber W. Kinetics of Adsorption on Carbon from Solution. J Sanit Eng Div [Internet]. 1963 [cited 2020 Jul 22];89(2):31-60. Available from: https://cedb.asce.org/CEDBsearch/record.jsp? dockey $=0013042$

19. Wu F, Tseng R, Journal RJ-CE, 2009 undefined. Characteristics of Elovich equation used for the analysis of adsorption kinetics in dyechitosan systems. Elsevier [Internet]. [cited 2020 Jul 22]; Available from:

https://www.sciencedirect.com/science/article/pii/S 1385894709000163

20. Langmuir I. The adsorption of gases on plane surfaces of glass, mica and platinum. J Am Chem Soc [Internet]. 1918 Sep 1 [cited 2020 Jul 22];40(9):1361-403. Available from: https://pubs.acs.org/doi/pdf/10.1021/ja02242a004.

21. Chemie HF-Z für physikalische, 1907 U. Über die adsorption in lösungen. degruyter.com [Internet]. [cited $2020 \mathrm{Jul} 22$ ]; Available from: https://www.degruyter.com/downloadpdf/j/zpch.19 07.57.issue-1/zpch-1907-5723/zpch-1907-5723.xml

22. Tempkin MI, Pyzhev V. Kinetics of ammonia synthesis on promoted iron catalyst. Acta Phys Chim USSR [Internet]. 1940 [cited 2020 Jul 22];12:32756. Available from:

https://ci.nii.ac.jp/naid/20000744365/

23. Dubinin MM, Radushkevich LV. The equation of the characteristic curve of activated charcoal. 55, 331 (1947). Proc Acad Sci USSR Phys Chem Sect [Internet]. 1947 [cited 2020 Jul 22];55:327-9. Available from:

https://ci.nii.ac.jp/naid/10028158033/

24. Sousa HR, Silva LS, Sousa PAA, Sousa RRM, Fonseca MG, Osajima JA, et al. Evaluation of methylene blue removal by plasma activated palygorskites. J Mater Res Technol. $2019 ; 8(6): 5432-42$.

25. Wang SY, Tang YK, Li K, Mo YY, Li HF, Gu $Z Q$. Combined performance of biochar sorption and magnetic separation processes for treatment of chromium-contained electroplating wastewater. Bioresour Technol. 2014;174:67-73.

26. Mezenner NY, Bensmaili A. Kinetics and thermodynamic study of phosphate adsorption on iron hydroxide-eggshell waste. Chem Eng J. 2009;147(2-3):87-96.

27. Farouq R, Yousef NS. Equilibrium and Kinetics Studies of adsorption of Copper (II) Ions on Natural Biosorbent. Int J Chem Eng Appl. 2015;6(5):319-24.

28. Subhash Kumar M, Rajiv P, Rajeshwari S, Venckatesh R. Spectroscopic analysis of vermicompost for determination of nutritional 
quality. Spectrochim Acta - Part A Mol Biomol Spectrosc [Internet]. 2015 [cited 2020 Jul 22];135:252-5. Available from:

https://www.sciencedirect.com/science/article/pii/S 1386142514010786

29. Wu Z, Zhong $H$, Yuan $X$, Wang $H$, Wang $L$, Chen $X$, et al. Adsorptive removal of methylene blue by rhamnolipid-functionalized graphene oxide from wastewater. Water Res [Internet]. 2014 [cited 2020 Jul 22];67:330-44. Available from:

https://www.sciencedirect.com/science/article/pii/S 0043135414006563 